\title{
MY MEN FORGIVING WINTER'S GAZE
}

Katie Price

for Bill Maguire

How behind our heads was the source of light.

How it reflected back on our faces from the screen.

Blue-grey, across our skin.

Reflected the body of the king,

The bodies of the boys.

The story their muscles acted out.

How you took it in with the more sensitive eye closed.

The other squinting with infection,

Squeezing out water onto the skin of your face.

How it wouldn't wash off.

How even to reflected light you were no longer immune.

(Within a year you would be completely blind-

It would be the director's last work.)

You kept trying to not see the movie,

Leaning into me as if to ask me something.

Your shoulder another bone wearing your skin

Thinner each month, pointing at something inside me.

How could we have left. We were exactly in the center.

The row was full. Musk of other men sweating

All around us. Faces pointed dead ahead

Like projectors. Faces steadfast as the screen. 
But your Adam's apple_pale buoy

Disappearing under the rhythms

Of swallowing. When the king took the boy

We all swayed together, vanishing

Together, swaying into the blue-grey light

That swayed like the skin of a great whale,

That kept diving under and coming back up-

Diving under the bodies on screen,

Coming back up over our bodies-

Diving under all that was the king's,

Then resurfacing over all that was ours-

And on the surface your eye watering back

Towards the movie, wanting to not see,

In the squint the rhythms of half-blinks,

Of whatever bodies that were still

Arousing the surface, pressed flat, washed clean, Until all the bodies in the story were fluid, Fading on screen, the blue-grey spew of breath- 